\title{
単分子層以下の流動潤滑薄膜の拡散・修復特性に関する基礎方程式
}

小野 京右 ${ }^{* 1}$

\section{Diffusion equation for spreading and replenishment in submonolayer lubricant film}

\author{
Kyosuke ONO ${ }^{* 1}$ \\ ${ }^{* 1}$ Emeritus Professor of Tokyo Institute of technology \\ 4-10-1 Shimoigusa, Suginami-ku, Tokyo 167-0022, Japan
}

\section{Received 26 February 2014}

\begin{abstract}
In magnetic hard disk drives, it is important to evaluate head wear durability in relation to lubricant layer because the head-disk spacing has to be reduced to $\sim 1 \mathrm{~nm}$ to achieve a high density recording above $1 \mathrm{~Tb} / \mathrm{in}^{2}$. This paper presents a new one dimensional diffusion equation to evaluate the replenishment process of a depleted lubricant groove in submonolayer thickness region. Basic equation is derived from a hypothetical concept that the ratio of submonolayer lubricant thickness to monolayer thickness is equal to that of local molecule density to bulk density. Equation of disjoining pressure is also modified from this concept. The local effective viscosity in submonolayer region is assumed to change linearly between solid boundary and monolayer thickness. The derived diffusion equation is nonlinear with respect to lubricant thickness. Calculated examples of spreading and replenishment behaviors are shown in comparison with those of the conventional theory. It was found that the spreading and replenishment speed similar to the experimental data can be obtained by using a realistic viscosity in submonolayer region compared to the conventional theory.
\end{abstract}

Key words : Tribology, Nanotribology, Head-disk interface, Submonolayer lubricant flow, Diffusion equation, Lubricant spreading, Lubricant replenishment

\section{1. 緒言}

磁気ディスク装置では，高密度化のために磁気ヘッドと磁気媒体間のすきまを小さくすることが重要である. 最近の磁気ディスク面では perfluoropolyether (PFPE) 潤滑膜が単分子層厚さ相当の 1.0 1.6 nm が塗布され，その 潤滑膜面と磁気へッド面との浮上寸きまが 1 2 nm となっている (Waltman, et al., 2010). 本研究が対象とする潤 滑膜は, ディスクを潤滑剤の溶融夜の中に磁気ディスクを浸して一定の速度で引き上げる dip 法によって塗布さ れ，高温または紫外線処理によりディスク面への結合力を高めている．極性末端基により DLC 面へ結合した成 分は固定層とよばれガラス相の固体に等しいと考えられている．固定層はDLC 膜の表面エネルギーを低下させ ることにより吸着力と摩擦力を低下させ，また等価的なヤング率も小さいのでヘッドスライダがディスクと突 起接触したときの接触応力を緩和させる効果があると考えられる。一方流動成分は，厚い場合へッドスライダ 側へピックアップされ浮上すきまを増加させる原因ともなるが，突起接触したとき潤滑効果を有し吸着力と摩 擦力を低下させ，固定層の摩耗を防ぎ，突起接触により排除されても修復できる効果がある，摩擦力を最小と する固定成分と流動性分の配分には最適值があり（Kawaguchi, et al., 2003），現状では単分子層の 80\%程度が固 定成分となっている.

現在高記録密度化のため浮上すきまを更に $1 \mathrm{~nm}$ 以下にすることが望まれているが, 突起接触の確率が増加し, ヘッド摩耗が問題となる。このため最近ヘッドの接触による流動潤滑剤の修復特性および潤滑剤とヘッド摩耗 との関係についての関心が高まっている.Canchi and Bogy (Canchi and Bogy, 2011) は Thermal Flying Height Control (TFC) ヘッドを各種の潤滑剤を塗布した磁気ディスクに接触させ，その結果生じた排除溝とその修復特性を実

\footnotetext{
No. 14-00111 [DOI: 10.1299/transjsme.2014mn0271]

*1 正員, 名誉員（干167-0022 東京都杉並区下井草 4-10-1)

E-mail of corresponding author: ono kyosuke@nifty.com
} 
験的に比較検討している. Matthes (Matthes, et al., 2013）は TFCへッドをディスク面に微小ずつ接触させていっ たときのヘッド摩耗と潤滑剤およびその bond 率との関係を実験的に研究し, 流動性分がヘッドの而摩耗性を向 上させることを示している.

流動潤滑膜の拡散特性については, 2000 年代の初めに盛んに研究された. Marchon and Karis (Marchon and Karis, 2006）は連続流体のポアズイユ流れと分離圧に基づく拡散方程式が数ナノメートルの潤滑膜境界の拡散特性を 定量的に評価できることを示した．単分子膜以下の領域を含む潤滑剤の流動特性の実験研究については,

Scarpulla ら(Scarpulla, et al., 2003) が潤滑膜の上面に気体を流して剪断力を与えたときの潤滑膜高さ分布の変化 から，等価的な粘度の膜厚さ依存性を測定している. これによると, 単分子膜厚さ以下の粘度は, バルクの粘 度に比べて, 非極性の潤滑剤の場合は低下し, 極性潤滑剤の場合は増加寸ることが示されている，一方，Itoh ら(Itoh, et al., 2008) はガラスファイバーの先端に付けた微小なガラス球を横振動させつつ磁気ディスク面に接 近させ，その応答から潤滑薄膜の粘性と弾性特性を計測し， $1 \mathrm{~nm}$ 程度に微小な間隙の等価粘度はバルクの值の 20 倍以上になることを示している.

連続体力学に基づく拡散方程式は，少なくとも単分子膜以上の潤滑膜の流動を定量的に評価できることが理 解されているが，単分子膜以下の領域の流動特性に適用できるか否かは不明であり，むしろ適用できないはず であると考えられてきた．そこで筆者は実際の磁気ディスクに用いられているZ-tetraol 潤滑剤の修復特性を， 従来の連続体力学に基づく拡散方程式を用いて解析し, 潤滑膜の等価的な粘度を同定すれば実験にかなりよく 一致する結果が得られることを示した(小野, 2013). しかし，同定される粘度は Hamaker 定数を $10^{-19} \mathrm{~J}$ と仮定す れば 50 100 Pa·s とかなり高いこと, 排除痕が深い場合と浅い場合で等価粘度に 2 倍近い差があることが示され た. 一方 Mate (Mate, 2013) は非極性・極性の各種の潤滑剤の微小液滴が拡散する現象について実験し, Z-18120 とZdol-6040 については, 中央部の高さが $0.8 \mathrm{~nm}$ 以下になったパンケーキ形の潤滑膜の拡散形状は従来の拡散 方程式で等価粘度を実験的に同定することにより広い時間領域で定量的に評価できることを示した.

単分子膜厚さ以下の潤滑膜の拡散流動を連続体力学に基づく拡散方程式で評価することは疑問視されている が，結果的に Hamaker 定数と粘度との比を実駼結果に適合するように選択すれば，広い範囲で拡散現象を定量 的にもかなりよく評価できる根拠は不明のままである．更にピックアップされたスライダ面の潤滑剤の流動， 熱補助記録における潤滑膜の挙動などを, 従来の連続体力学による拡散基礎式に基づく式を用いて解析し, 実 験結果との定量的な比較のない論文が多数報告されている. そこで本研究では，単分子層以下の液膜厚さの測 定値は，その厚さにおける分子密度の単分子層以上の膜厚さにおける分子密度に対する比で表されるという事 実に注目し, 潤滑薄膜の密度に関する量はバルクの密度の単分子層厚さと潤滑膜厚さとの比で表されるという モデルに基づき, 単分子層以下の潤滑膜の平均的な流動に対する基礎式を導出した. また単分子層以下の膜厚 さにおける等価粘度は厚さに関して線形的に変化するモデルを採用した. 基礎式は二次元流動のモデルを考え ることができるが，ここでは基礎式の特徴を明確にし，また従来の拡散方程式と比較しやすくするために一次 元方向の拡散流動の定式化を行う.

得られた新しい拡散方程式により潤滑膜境界面の拡散特性を解き，従来の拡散方程式と同じ特性が得られる 等価粘度について比較検討した. また前報(小野, 2013)で示した実際の潤滑膜の修復特性の実験值と比較した。 その結果, 自由表面をもつ単分子層以下の膜において実際に計測されるような粘度の值 (Scarpulla, et al., 2003) を用いて，従来理論でかなり高い粘度を用いた場合とほぼ同じ拡散特性が得られることが明らかになった

第 3 章では，単分子膜以下の流動のモデルを定式化し，これを用いて単分子層以下の液膜の拡散方程式を導 出する．第 4 章ではこれを用いて液膜境界の拡散特性および実際にヘッドの接触によって生じた流動潤滑剤の 排除溝の修復特性を従来理論と比較的に示す．第 5 章では本研究で得られた結果をまとめる.

\section{2. 記号 · 単位}
$A \quad$ ：従来理論による Hamaker 定数 [J]
$A_{m}$ ：単分子膜以上の均一密度における Hamaker 定数 [J]
$D_{0} \quad:=d_{d} / h_{0}$ 


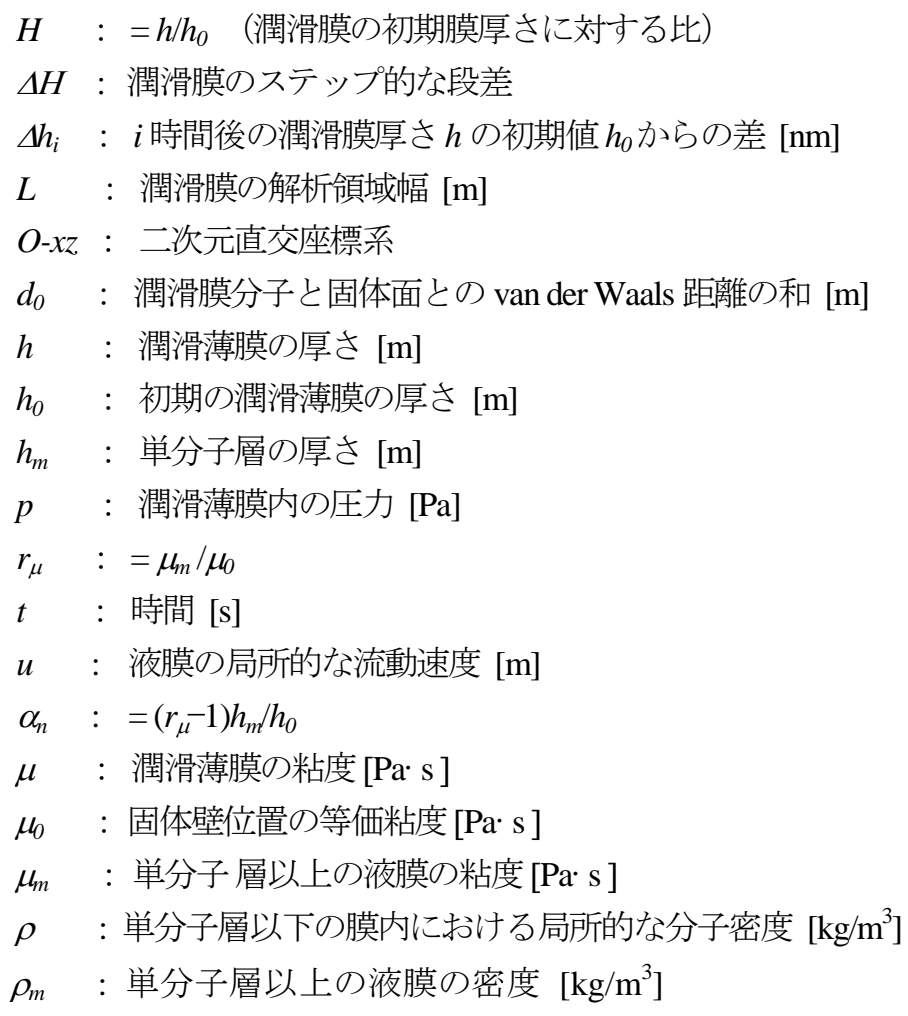

\section{3. 単分子膜以下の液膜の拡散方程式}

\section{$3 \cdot 1$ 解析モデルと仮説の定式化}

図 1(a) に単分子層厚さ以下の潤滑液膜内の圧力流れのモデルを示す. 液膜表面に作用する気体の剪断応力, 周 囲圧変化および膜厚さに依存する分離圧による液膜境界面の拡散，または固体面の接触摺動によって排除された 溝に周囲から潤滑剤が流入し排除溝が修復される現象などを解析寸るためのモデルである. 流れ方向に $x$ 座標を, 厚さ方向に $z$ 座標を設定寸る. $z=0$ は固体壁面ないし固定層との境界面と寸る. $h_{m}$ は単分子層の厚さ（分子の回 転直径) である．単分子層厚さ以下の液膜の流動に関して以下の仮定をおく.

(1) 液膜の厚さと密度との関係 まず, 表面の高さ $h$ が単分子層以下の場合には, 液膜分子が密に存在しておら ずその密度は多分子層膜領域の密度 $\rho_{m}$ より小さい. Optical Surface Analyzer (OSA) 等で測定される潤滑液膜の厚 さ $h$ の単分子層厚さ $h_{m}$ に対する比は, $h$ における潤滑剤分子の密度 $\rho$ の単分子以上の潤滑剤の密度 $\rho_{m}$ に対 する比に相当すると考えられる，即ち，単分子層以下の液膜厚さ $h$ は次式で定義できる.

$$
h=h_{m}\left(\rho / \rho_{m}\right) \text { or } \rho=\rho_{m}\left(h / h_{m}\right)
$$

現在，実際の垂直記録用磁気ディスク面には磁性粒子構造による粗さがあり，その大きさは $\mathrm{rms}$ 值で $0.3 \mathrm{~nm}$ 程 度である.これは潤滑剤分子直径の 1/3 1/5 程度なので潤滑剤分子にとってディスク面はほぼ滑らかな平面と考 えることができる．また磁性粒子の突起間の平均距離は $10 \mathrm{~nm}$ 程度で(小野, 2011), Z-tetraol 潤滑剤分子の高さは $1.7 \mathrm{~nm}$, 投影面積は $10 \mathrm{~nm}^{2}$ 以下と予想される（Tani, et al., 2009）。よって被覆率 1 の潤滑剤分子密度は突起密度の 10 倍以上あり, 平均厚さ $0.3 \mathrm{~nm}$ の流動分子は突起密度の 2 倍程度で, $1 \mu \mathrm{m}^{2}$ 当り 1 万個以上あり, 平均厚さが 0.03 $\mathrm{nm}$ になったとしても $1 \mu \mathrm{m}^{2}$ 当り 1000 個以上ある. よってディスク平面上の潤滑剤の $1 \mu \mathrm{m}^{2}$ 程度の面積の平均流 動に注目すれば，式(1)に示寸潤滑膜の平均厚さを定義することができる. また以下に述べる平均的な流動速度お よび平均圧力も $1 \mu \mathrm{m}^{2}$ 程度の分解能で定義することができる.さらにこれらの平均的な物理量は, $1 \mu \mathrm{m}^{2}$ 程度の分 解能で連続関数で表現することができるので，従来の連続体理論のように扱うことができると考えられる. 


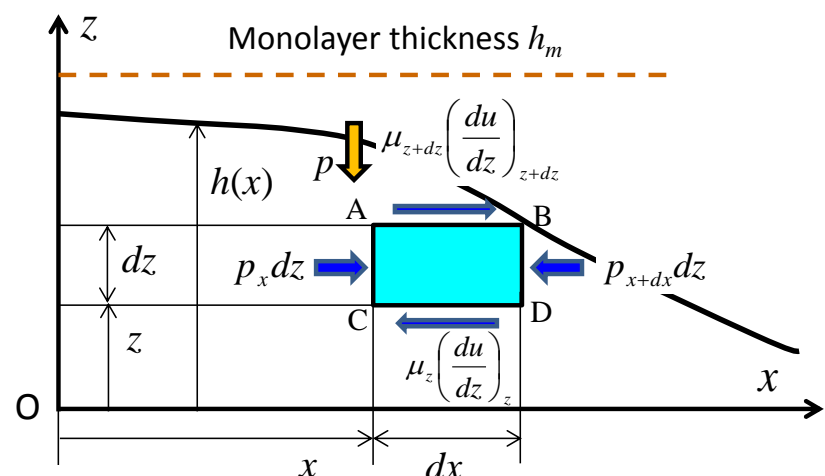

Fig.1 Coordinates system and forces acting on a small liquid element inside submonolayer film near liquid surface.

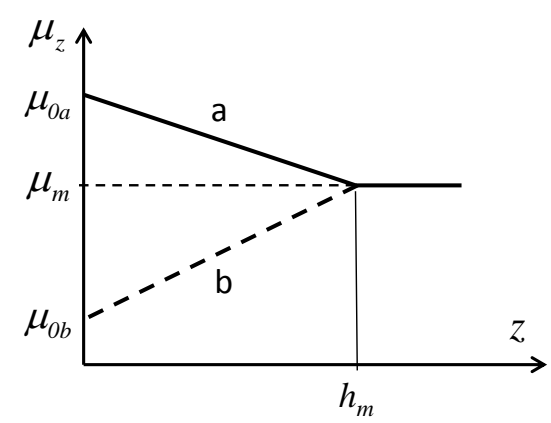

Fig. 2 Model of lubricant viscosity as a function of height $z$ in submonolayer film.

一方，現在の潤滑膜厚さを計測する機器の空間分解能は $1 \mu \mathrm{m}^{2}$ 程度なので，計測される潤滑膜厚さは少なくと も分子 1000 個以上の平均值であり，後に示すように膜厚さの実験值はほぼ連続した高さ分布を有する.よって本 論文で提案する単分子膜以下の平均的な流動に対する連続体理論は, 実験で計測される膜厚さに整合していると いうことができる.

(2) 液膜内の流動速度のモデル 図 1 を参考に, 厚さ $h(x)$ の液膜の表面の速度, 内部の座標 $z$ における流速 $u$, 歪 み速度 $d u / d z$ とは何かを考える. まず単分子層以下の厚さ $h$ の液膜表面に剪断応力が作用して, 表面に流動速度 $u(h)$ が生じたとする.もし潤滑剤分子が回転直径 $h_{m}$ の剛体球で, 密度 $\rho(h)$ の分子が一様に速度 $u$ をもつとすれば, 球体分子は壁面ではスリップないし転がり，密度 $\rho(h)$ の分子全体が速度 $u(h)$ をもつことになる．しかし極性をも つZ-dol 潤滑剤の Pancake 形の単分子膜以下の拡散流動は，スリップはないとしたポアズイユ流れのモデルで定 量的に評価できることが示されている (Mate, 2012). 潤滑剤分子は主鎖をもち紐状をなしているので ( Scarpulla, et al., 2003)，単分子膜以下の領域でも剪断を受けて流動する分子は層状をなし，その流動速度は $z$ 位置で変化し ており，固体壁面に近づくにつれて流動速度はゼロになると考えられる．このような考え方に基づき，単分子以 下の液膜内でも高さ $z$ によって変化する速度 $u(z)$ の存在を仮定する. Scarpulla らによる blow-off 実験によれば, 単分子層以下の膜厚さで Zdol のモビリティーがほぼ線形的に減少しており， $h=0$ のときモビリティーがゼロと なっている．また斉藤ら( 斉藤他，2010)によるモビリティーの分子動力学解析によると, Z-tetraol の潤滑剤薄膜 は上記 Zdol の blow-off 実験と同様の結果を得ている．これらはここでの仮説の正当性を示している.

ただしこの流動モデルは液膜厚さが主鎖の直径太さ近傍まで薄くなると成立しなくなると考えられる．しかし その場合でも，液膜表面近傍ではこのモデルが成立すると考えられる．これを理解するために，図 1 に示すよう に表面近傍の微小要素 $d x \times d z$ に注目寸る. 微小要素の上面 (A-B) の $z+d z$ 位置の速度 $u(z+d z)$ は表面高さ $h(\mathrm{z}+d z)$ の分子密度の平均分子速度で近似できる. 同様に微小要素の下面 (C-D) の $z$ 位置の速度は表面高さ $h(z)$ の平均速 度で近似できると考えられる．液膜分子が固体壁面でスリップがないとすれば，これらの $u(z), u(z+d z)$ は異なる速 度をもち，よってその変化率と 2 次変化率を考えることができる．このように表面近傍の流動速度 $u(z)$ は表面 高さ $h=z$ における流動速度 $u(h)$ に等しく, 膜厚さ $h$ に対応して連続的に変化すると考えられる.

単分子層以下の液膜の流動が, 紐状の主鎖が多層に滑る構造をもたないような薄い潤滑膜の場合, 表面位置 $z=$ $h\left(x_{I}\right)$ の近傍でなく, その $x_{I}$ 位置で液膜内部位置 $z_{I}$ における分子の平均速度 $u\left(x_{1}, z_{I}\right)$ を, 表面高さが $h\left(x_{2}\right)=z_{I}$ となる速度に等しいと考えることができるか否かは不明である.ここでは，液膜は薄いため液膜分子は上下方向 には移動しないので，表面近傍と同様に $\mathrm{z}$ で変化する速度分布 $u(z)$ が存在していることを仮定する.

以上の考察によって, ここでは単分子以下の液膜内においても, 表面近傍では, $z$ 位置で変化する分子の $x$ 方 向平均速度が存在し, 各層面に作用寸る剪断応力はニュートン流体のように, その層面における剪断歪速度に比 例すると仮定する．そこでの局所的な比例定数を粘度 $\mu_{z}$ とし， $z$ 位置面における剪断応力を $\tau_{z}$ とすると，

$$
\tau_{z}=\mu_{z} \frac{d u}{d z}
$$


の関係が成り立つ.ここで粘度は $z$ 方向に一定ではなく, 一般的には $z$ の関数である.

(3) 粘度のモデル 次に粘度 $\mu_{z}$ の厚さ方向の変化について考察する. 単分子膜以下の粘度特性について Scarplla ら(Scarplla, et al., 2003) は, 潤滑膜表面に気体を流し気体と液体との摩擦剪断応力により変化する膜境界形状を測 定する blow-off 実験を行い，膜厚変化率から各種潤滑剂の等価粘度の膜厚依存性を測定した。これによると， PFPE主鎖にアルコールの末端基をもちシリコンウエハ面に水素結合するDemnum-SAは，1 nm以下の膜厚ではバ ルクの数十倍大きな等価粘度をもつが, 中性の-CF3末端基をもつDemnum-S20は, 膜厚さ $0.5 \mathrm{~nm}$ 以下ではむしろバ ルクよりも小さな值となっている．またDemnum-SA上にDemnum-S20を塗布したサンプルでは，0.5 nm以下では 更に小さな粘度が得られている. 更に, 両端に一つの極性基をもつZdolの粘度は, 流動層でバルクの数倍となり, 固定層では100倍近くなることを示している. 一個の分子の歪速度に対する抵抗力である粘度が一定とすれば, 単 分子以下の層における粘度は, 膜厚さ $h$ の減少に比例して等価密度が低下寸るので, 平均的な粘度が低下し, $h=$ 0でゼロに近くなるはずである. 非極性潤滑膜における粘度が単分子膜以下でバルクより小さくなるのは, 主とし てこの分子密度の減少効果ためと考えられる．しかし極性末端基をもつ潤滑膜の場合には，固体面で分子密度の 低下以上に固着力の増大が大きくなると考えられる.

図 2 は, 単分子膜厚さ $h_{m}$ のときの粘度を $\mu_{m}$ としたときの単分子膜厚さ以下の厚さにおける粘度のモデルであ る. 固体壁面位置 $z=0$ における粘度が $\mu_{m}$ より大きくなる $\mu_{0 a}$ の場合と $\mu_{m}$ より小さくなる $\mu_{o b}$ の場合がある. Scarpllaら(Scarplla, et al., 2003) およびMate (Mate, 2013) の実験によれば，極性潤滑剤の単分子層以下の粘度はバ ルクの粘度に比べて増加し, モデル $a$ のように $\mu_{0 a}>\mu_{m}$ となっており, 一方, 非極性潤滑剤の場合はバルクの粘 度より小さくなり, モデル $b$ のように $\mu_{0 b}<\mu_{m}$ となっていると考えられる.

ここで $\mu_{m}$ は単分子層における粘度であるが, 表面力装置で測定される広い領域に押し込まれた数分子層以下の 粘度はバルクの粘度から100倍以上に増大寸ることが知られている (Granick, 1991). またItohら (Itoh, et al., 2008) の直径 $0.2 \mathrm{~mm}$ の球による fiber wobbling法実験によっても, 粗さ接触近傍の等価粘度はバルクの30倍程度にもな ることが報告されている．しかしこれらの場合は狭小領域に押し込まれた流動層の粘度である. 自由表面の拡散 現象における単分子層レベルの粘度は, Scarpllaらの blow-off 実験結果(Scarplla, et al., 2003)のように, バルクの粘 度に近いと予想される。

Blow-off 実験によって測定される単分子層膜以下の等価粘度は膜厚さhにおける膜表面の值であり，この值が 膜内部の $z$ 位置の粘度 $\mu_{z}$ に等しいか否かは議論の余地がある. しかしここでは膜内部の $z$ 位置の粘度が膜厚さ $h$ の 粘度で近似できると仮定する． $\mu_{0}$ から $\mu_{m}$ への変化曲線は潤滑剤ごとに異なるが，ここでは数学的な取り扱いが 容易になることをも考慮し, $z=0$ で $\mu_{0}$, 単分子層厚さ $\mathrm{z}=h_{m}$ で $\mu_{m}$ となり,

$$
\mu_{z}=\mu_{0}(1+\alpha z)
$$

で表される線形的に変化する粘度モデルを仮定する．ここで $\alpha$ は

$$
\alpha=\frac{\left(\mu_{m}-\mu_{0}\right)}{\mu_{0} h_{m}}=\frac{\left(r_{\mu}-1\right)}{h_{m}},\left(r_{\mu}=\frac{\mu_{m}}{\mu_{0}}\right)
$$

で与えられる.

なお, Scarplla らの実験結果 (Scarplla, et al., 2003) によれば, Zdol の単分子以下の膜厚の等価粘度は一定で, バ ルクの粘度の值から不連続的に変化しているように見える. 式(3)を用いて導出する以下の基礎式はこの場合も含 んでおり，基礎式において $\alpha=0$ とし， $\mu_{0}$ に単分子層以下の粘度を用いればよい.

(4) 圧力流れに関する基礎式 拡散・修復現象では液膜の表面張力は無視できることが分かっているので，ここ では表面張力作用を無視する. 上に述べた液膜のレオロジー的性質を仮定したうえで, 図 1 に示す微小要素 $d x \times d y$ に作用寸る力の釣り合いを考える. 図 1 において，圧力 $p$ は上表面に作用する周囲圧力か，潤滑膜の固体面から の van der Waals 力によって生じる分離圧である. これらの圧力は液膜表面に作用し, 膜厚さ方向には一定に浸透 寸るので $x$ 座標のみの関数である. $x$ および $x+d x$ 位置の $d z$ 面, また $z, z+d z$ 位置の $d x$ 面にはそれぞれ図に示す 力が作用しているから，微小要素の釣り合い式は次式で書ける. 


$$
p_{x} d z-p_{x+d x} d z+\mu_{z+d z}\left(\frac{d u}{d z}\right)_{z+d z} d x-\mu{ }_{z}\left(\frac{d u}{d z}\right)_{z} d x=0
$$

通常の無限小解析法に基づいて整理すると，単分子層以下の分子の統計的に平均化した流動速度に関する表現 として以下の方程式を得る.

$$
\frac{d}{d z}\left(\mu_{z} \frac{d u}{d z}\right)=\frac{d p}{d x}
$$

ただし，この微分方程式は， $\mathrm{z}$ 方向には流動分子の平均膜厚さが分子密度に比例するという条件が $0.01 \mathrm{~nm} レ$ ルまで成立すると仮定し, $\mathrm{x}$ 方向には $\mu \mathrm{m}$ レベルの分解能で平均化した膜厚さ, 流速, 圧力の変化がそれより微小 な領域でも成立すると仮定した無限小解析モデルに基づく表現式である. よってこれを数值計算する際に離散化 した式が，上記の分解能の範囲で成立する基礎式であると考えるべきである.

\section{$3 \cdot 2$ 拡散方程式の導出}

式(5)を $\mathrm{z}$ で積分し， $z=h$ の流動膜表面の剪断応力を $\tau_{h}$ とすると,

$$
\mu_{z} \frac{d u}{d z}=\frac{d p}{d x}(z-h)+\tau_{h}
$$

が得られる. Blow-off 実験法で粘度の膜厚さ依存性を測定するには, この式に $z=h$ を代入した式が利用される. 以下では自由表面の拡散現象を取り扱うので， $\tau_{h}=0$ とすると，

$$
\frac{d u}{d z}=\frac{1}{\mu_{z}} \frac{d p}{d x}(z-h)
$$

となる.式(3)で表される粘度を $\mu_{z}$ に代入して $z$ で積分し, 固体壁面でスリップがない条件で積分定数を決めると, 次の速度分布の解を得る.

$$
u=\frac{1}{\alpha \mu_{0}} \frac{d p}{d x}\left(z-\frac{1+\alpha h}{\alpha} \ln (1+\alpha z)\right)
$$

$x$ 位置の連続の式は次式で与えられる.

$$
\frac{\partial \rho h}{\partial t}+\frac{\partial}{\partial x} \int_{0}^{h} \rho u d z=0
$$

左辺第 2 項の積分部分を $q$ として, 密度 $\rho$ に式(1)を用いると, $q$ は次式で表される.

$$
q=\int_{0}^{h} \rho u d z=\frac{\rho_{m} h}{\alpha \mu_{0} h_{m}} \frac{d p}{d x} \int_{0}^{h}\left(z-\frac{1+\alpha h}{\alpha} \ln (1+\alpha z)\right) d z
$$

係数の分母に $\alpha$ あるあので, $\mu_{m}=\mu_{0}$ で $\alpha=0$ のとき不定となる. そこで $|\alpha z|<|\alpha h|<1$ のときの近似積分式を求 める. $\ln (1+\alpha z)$ をテイラー展開し， $\alpha z$ に関して 2 次項までをとると, 次式となる. 


$$
q=\int_{0}^{h} \rho u d z=-\frac{\rho_{m}}{3 \mu_{0} h_{m}} \frac{d p}{d x} h^{4}\left(1-\frac{\alpha h}{4}+\frac{\alpha^{2} h^{2}}{10}\right)
$$

一方，式(10)をそのまま積分すると次式が得られる.

$$
q=\int_{0}^{h} \rho u d z=-\frac{\rho_{m}}{\mu_{0} h_{m}} \frac{d p}{d x} I(h)
$$

ここで

$$
I(h)=\frac{h}{\alpha}\left(h+\frac{1}{\alpha}\right)^{2} \ln (1+\alpha h)-\frac{3}{2 \alpha} h^{3}-\frac{h^{2}}{\alpha^{2}} .
$$

次に $d p / d x$ を潤滑膜の分離圧から求める. 分離圧には複数の発生原因があるが，主として液膜分子と固体壁面 との van der Waals 力による吸着力に起因する (Mate, 2008, 2011). 薄い場所の方が液体分子の固体壁面への引力が 強いので, 厚い領域の液体を薄い領域に引き込み厚さを大きくするよう作用するので分離圧と呼ばれている. 厚 さ $h$ のPPE 潤滑膜の分離圧は多くの文献において

$$
p=-\frac{A}{6 \pi} \frac{1}{\left(h+d_{0}\right)^{3}}
$$

が用いられている．ここで $A$ は単分子層以上の膜における固体面と液膜の Hamaker 定数である. $d_{0}$ はカットオフ 距離とよばれ，液体分子と固体壁分子がこれ以上接近できない分子間距離を連続体理論として等価的に評価した 值に相当する (Israelachvili, 1992). 式(14)が単分子層以下の液膜に適用できるか否かは議論の余地があるが，適用 しても実験結果と矛盾しないと考えられており (Mate, 2011, 2013)，1 nm 以下の潤滑膜厚領域まで式(14)ないし式 (14)に整合する表面エネルギーの式を適用して実験的に $d_{0}$ が求められている(Matsuoka, et al., 2010, Tani, et al., 2013)．そこでこの式を前提とする. しかし式(14)は均質の液膜の密度を前提とした式である. Hamaker 定数の中 には均質な液膜の密度が含まれているので(Israelachvili, 1992), ここでは

$$
A=A_{m} \frac{h}{h_{m}}
$$

とし，これを式(14)へ代入した

$$
p=-\frac{A_{m}}{6 \pi h_{m}} \frac{h}{\left(h+d_{0}\right)^{3}}
$$

を用いる。これから

$$
\frac{d p}{d x}=\frac{A_{m}}{3 \pi h_{m}} \frac{\left(h-d_{0} / 2\right)}{\left(h+d_{0}\right)^{4}} \frac{d h}{d x}
$$

となるので, 式(17)を式(11)へ代入し, 次にこれを式(9)へ代入し, 式(1)を用いて整理すると, 以下の拡散方程式 を得る。 


$$
\frac{\partial h^{2}}{\partial t}=\frac{A_{m}}{18 \pi \mu_{0} h_{m}} \frac{\partial}{\partial x}\left[\frac{\left(h-d_{0} / 2\right) h^{3}}{\left(h+d_{0}\right)^{4}}\left(1-\frac{\alpha h}{4}+\frac{\alpha^{2} h^{2}}{10}\right) \frac{d h^{2}}{d x}\right]
$$

一方，テイラー展開しない厳密な解は，式(17)を式(12)へ代入し，これを式(9)へ代入し，式(1)を用いて整理す ると，次の拡散方程式となる.

$$
\frac{\partial h^{2}}{\partial t}=\frac{A_{m}}{6 \pi \mu_{0} h_{m}} \frac{\partial}{\partial x}\left[\frac{\left(h-d_{0} / 2\right) I(h)}{h\left(h+d_{0}\right)^{4}} \frac{d h^{2}}{d x}\right]
$$

式(18)，(19)が単分子以下の膜厚さの液膜の拡散方程式である.

次章で示寸実際の計算では，基準となる液膜厚さ $h_{0}$ （修復特性では初期膜厚さ）からの変化を調べる場合が多 いので，無次元液膜厚さ $H=h / h_{0}$ を用いると，式(18)は

$$
\frac{\partial H^{2}}{\partial t}=\frac{A_{m}}{18 \pi \mu_{0} h_{m}} \frac{\partial}{\partial x}\left[\frac{\left(H-D_{0} / 2\right) H^{3}}{\left(H+D_{0}\right)^{4}}\left(1-\frac{\alpha_{n} H}{4}+\frac{\alpha_{n}^{2} H^{2}}{10}\right) \frac{d H^{2}}{d x}\right] \quad\left(H=\frac{h}{h_{0}}\right)
$$

で表される.ここで $D_{0}=d_{0} / h_{0}$ で，また $\alpha_{n}$ は

$$
\alpha_{n}=\alpha h_{0}=\frac{\left(r_{\mu}-1\right) h_{0}}{h_{m}}
$$

で表され，いずれも無次元量である。一方，式(19)は

$$
\frac{\partial H^{2}}{\partial t}=\frac{A_{m}}{6 \pi \mu_{0} h_{m}} \frac{\partial}{\partial x}\left\{\frac{\left(H-D_{0} / 2\right) J(H)}{\left(H+D_{0}\right)^{4}} \frac{\partial H^{2}}{\partial x}\right\}
$$

で表される.ここで $J(H)$ は

$$
J(H)=\frac{1}{\alpha_{n}}\left(H+\frac{1}{\alpha_{n}}\right)^{2} \ln \left(1+\alpha_{n} H\right)-\frac{3}{2 \alpha_{n}} H^{2}-\frac{H}{\alpha_{n}^{2}}
$$

で与えられる.

一方，従来の連続体力学に基づく一次元の拡散方程式は

$$
\frac{\partial H}{\partial t}=\frac{A}{6 \pi \mu h_{0}} \frac{\partial}{\partial x}\left\{\frac{H^{3}}{\left(H+D_{0}\right)^{4}} \frac{\partial H}{\partial x}\right\}
$$

\section{で与えられる.}

単分子層以下の液膜の拡散に関する基礎式(20)および(22)の従来理論との大きな違いは $H^{2}$ に関する微分になっ ており, 非線形性を示していることである. これは密度が膜厚さにより変化するからである. また $H(x)$ の関数と なっている拡散係数の分子が $\left(H-D_{0} / 2\right)$ となっており, $H=D_{0} / 2$ で等価的な拡散係数が零となり, これを境に符合 が変化する. この特徵の影響については次章で詳しく述べる. 次章では，定式化された単分子層以下の液膜の拡 散方程式(20), (22)と従来理論式(24)による拡散・修復特性を数值計算により比較する. 


\section{4. 単分子層以下の液膜に関する拡散方程式による拡散・修復特性}

\section{$4 \cdot 1$ 数值計算法}

式(20)，(22)，(24)を差分法により離散化し，液膜境界の拡散現象および既報の修復特性の実験デー夕に対する 計算を行い, 従来の連続体理論と比較する. 以下では, 式(20)を本理論近似解, 式(22)を本理論撖密解, 式(24)を 従来理論とよぶ. 共通に使用した物理パラメータは, Hamaker 定数 $A=0.5 \times 10^{-19} \mathrm{~J}$ （DLC-PFPE 潤滑剂一空気 の場合 $A=0.47 \times 10^{-19} \mathrm{~J}$ （松岡, 福井, 2003)）, 単分子膜厚さ $h_{m}=1.5 \mathrm{~nm}$ (Z-tetraol) とした. カットオフ距離 $d_{0}$ は 分子間距離を連続体として評価した值で $0.165 \mathrm{~nm}$ で与えられる (Israelachvili, 1992)。しかし実際には式(14)に基 づく固体面上の液膜厚さと表面エネルギーとの関係式を実験值と比較して求める場合が多く, DLC 上の極性潤滑 膜の場合 $0.17 \sim 0.6 \mathrm{~nm}$ の值が報告されている (Matsuoka, et al., 2010, Marchon and Karis, 2006, Tani, et al., 2013). 実 験において $0.165 \mathrm{~nm}$ より大きく評価されるのは，後述するように式(14)の単分子膜以下の領域一の適用限界によ ると考えられ，本論文では $d_{0}=0.2 \mathrm{~nm}$ とする. 本理論の基本的な拡散・修復特性を調べる場合の初期膜厚さは $h_{0}$ $=0.5 \mathrm{~nm}$ とした． 節 4.4 での実際の修復特性に関する計算の場合を除き，数值計算での解析領域は拡散現象の影 響が及ばない $L=100 \mu \mathrm{m}$ とし, 解析領域境界では一次微分をゼロとした. 解析幅は等間隔に 400 500 分割した.

\section{$4 \cdot 2$ 液膜境界の拡散特性}

まずステップ的に変化する液膜境界の拡散特性についての計算例を従来理論と比較的に示す. バルクの粘度が $1 \mathrm{~Pa} \cdot \mathrm{s}$ の Z-tetraol 潤滑膜の修復特性を従来理論により得るには, $A=1.0 \times 10^{-19} \mathrm{~J}, d_{0}=0.3 \mathrm{~nm}$ としたとき等価粘度 を $\mu=50 \sim 100 \mathrm{~Pa} \cdot \mathrm{s}$ にする必要があった (小野，2012). しかし $A=0.5 \times 10^{-19} \mathrm{~J}, d_{0}=0.2 \mathrm{~nm}$ とすると節 4.4 で示す ように, 従来理論では等価粘度を $60 \mathrm{~Pa} \cdot \mathrm{s} \sim 120 \mathrm{~Pa} \cdot \mathrm{s}$ にする必要がある. そこで従来理論では $\mu=90 \mathrm{~Pa} \cdot \mathrm{s}$ を用い, 本理論では バルクの $\mu_{m}=1 \mathrm{~Pa} \cdot \mathrm{s}$ を用いて従来理論と同様な拡散特性を示すような $r_{\mu}$ の值を選択した.

図 3(a), (b) は，液膜高さを $h_{0}=0.5 \mathrm{~nm}$ とし，薄い方の液膜高さが $H=0.5 （$ 段差 $\Delta H=0.5 ）$ の場合について, $r_{\mu}=0.2,0.3$ としたときの本理論の結果で, 図 3(c)は従来理論の結果ある. いずれも $600 \mathrm{~s}$ 毎の拡散した膜形状を $3600 \mathrm{~s}$ まで示している. 図3(d), (e), (f)はそれぞれ(a), (b), (c)の結果を $(x-0.5 L) / t^{1 / 2}$ の関数として図示したものであ

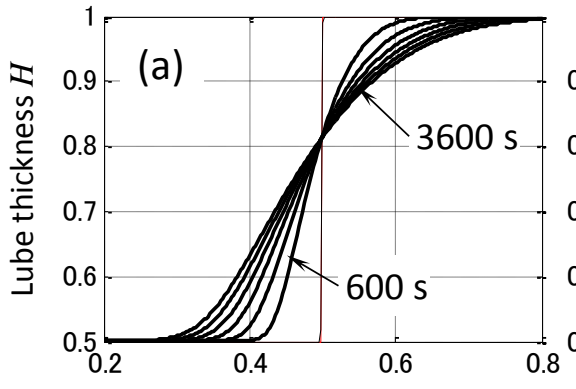

$x / L$

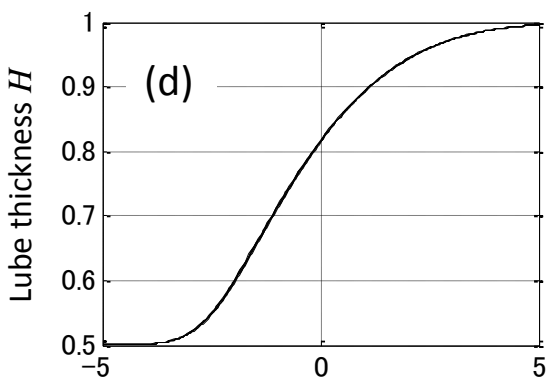

$(x-0.5 L) / t^{1 / 2}\left[10^{-7} \mathrm{~m} / \mathrm{s}^{1 / 2}\right]$

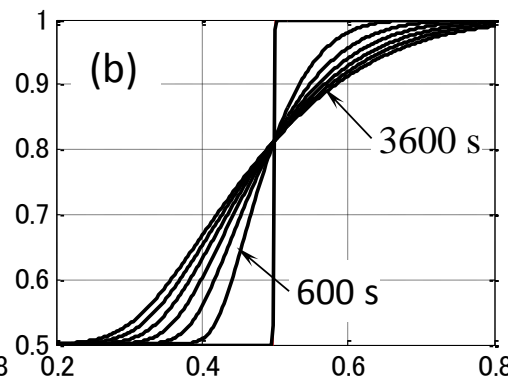

$x / L$

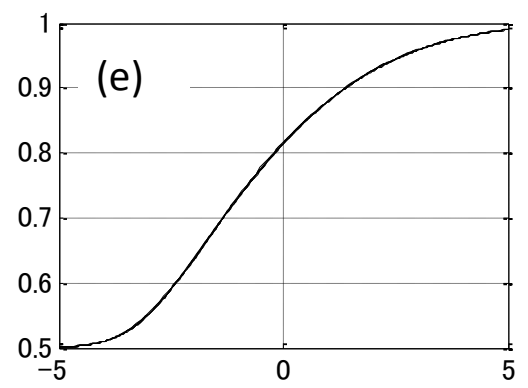

$(x-0.5 L) / t^{1 / 2}\left[10^{-7} \mathrm{~m} / \mathrm{s}^{1 / 2}\right]$

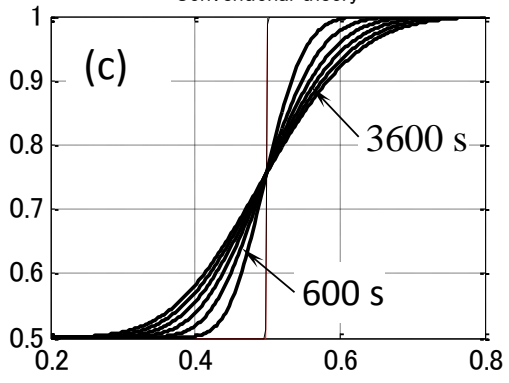

$x / L$

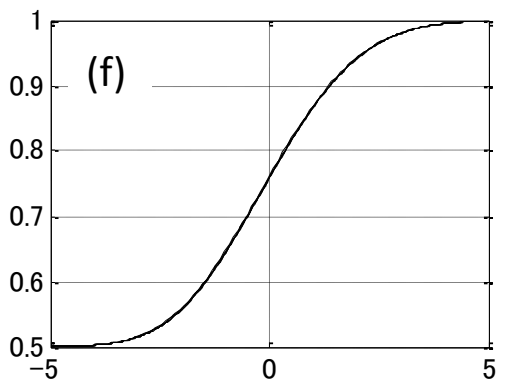

$(x-0.5 L) / t^{1 / 2}\left[10^{-7} \mathrm{~m} / \mathrm{s}^{1 / 2}\right]$

Fig. 3 Comparison of spreading profiles around film thickness step of $\Delta H=0.5$ when $h_{0}=0.5 \mathrm{~nm}$. (a), (d) Submonolayer theory: $\mu_{m}=1 \mathrm{~Pa} \cdot \mathrm{s}, r_{\mu}\left(=\mu_{m} / \mu_{0}\right)=0.2$. (b), (e) Submonolayer theory $\mu_{m}=1 \mathrm{~Pa} \cdot \mathrm{s}, r_{\mu}\left(=\mu_{m} / \mu_{0}\right)=0.3$. (c), (f) Conventional theory: $\mu=90 \mathrm{~Pa} \cdot \mathrm{s}$. 
る. $r_{\mu}=0.2,0.3$ のときそれぞれ $\alpha_{n}=-0.267,-0.233$ で, $|\alpha z|<|\alpha h|<<1$ なので, 節 4.3 で述べるように近似解は厳 密解と同じ値を示寸.

液膜段差が $\Delta H=0.5$ で, 薄い液膜高さが $H=0.5$ の場合, 本理論の拡散形状は従来理論と似ており, 拡散液膜 先端は単調に減少し $H=0.5$ での微係数がゼロとなっている. しかし段差境界位置での液膜高さは本理論の方が 大きくなっており, $x<0.5 L$ 側へ拡散した液膜体積の方が $x>0.5 L$ 側で失われた液膜体積より大きくなっている. これは薄い液膜は厚い液膜に比べて密度が低いので, 薄い領域に拡散した液の体積が増えるように見えるためで ある.また横軸を $(x-0.5 L) / t^{1 / 2}$ で表すと，本理論は $H^{2}$ に関する非線形方程式であるが，唯一の拡散形状で表され ることがわかる. 薄い液膜の高さが $H=0.5$ の場合は, 液膜先端の拡散速度は $r_{\mu}=0.2$ のときが従来理論の結果 に近い.

薄い液膜高さが $H=0.2$ の場合について, 図 3(a), (b), (c) と同様な計算結果を図 4(a), (b), (c)に示す.この条件下 では本理論の拡散液膜の先端は切り立っているのが特徴的である. これは $H=0.2$ のとき, $H-D_{0} / 2=0$ となるの で, 拡散方程式(20), (22)の係数がゼロとなり， $H=0.2$ における局所的な拡散係数がゼロとなるからである. この ため拡散液膜の先端が従来理論に近い速度を得るには壁面の等価粘度を小さくする必要があり, 液膜先端の拡散 位置は $r_{\mu}=0.3$ の方が従来理論に近い特性を示している. 従来理論でも式(24)から分かるように $\mathrm{H} \rightarrow 0$ では拡散係 数がゼロになるので, 液膜が液膜ゼロの面に拡散するときの液膜先端は図 3(a), (b) のように垂直に近くなる (小野, 2013).

図 3 および 4 に示した結果は, 従来理論により 推定される Z-tetraol の液膜境界の拡散速度に近い結果を本理論 で得るには，固体壁面の粘度がバルクの粘度の 3 5 倍にすればよいことを示している. Scarplla ら (Scarplla, et al., 2003) の blow-off 実験によればZdolの単分子層以下の膜の粘度は, バルクの 2 5 倍となり, また Mate (Mate, 2012) の微小液滴拡散実験によれば，Zdol の場合バルクの粘度の約 2 倍になることが報告されている．極性末端基を主 鎖の両端に 2 個ずつもつZ-tetraol の場合の測定例の報告はないが，図 3,4 に示寸結果は固定壁面の粘度をバルク の值の数倍にすればよく, 本理論はこれまで報告されている実験結果と整合している.

従来理論の拡散係数は，式(24)より $H^{3} /\left(H+D_{0}\right)^{4}$ で表されるが，単分子層以下の液膜に対する本理論式(20), (22) では分子に $\left(H-D_{0} / 2\right)$ の因子を含むので, $H<D_{0} / 2$ で拡散係数は負となり $D_{0} / 2$ より薄い液膜領域一の拡散特性は求 まらない. 数值計算では時刻 $t$ の $H$ の分布を用いて $t+\Delta t$ のときの $H^{2}$ について解くので, $H^{2}$ が負になり $H$ が複素 数になる. これは $H<D_{0} / 2$ の領域へは拡散しないことを意味すると考えられる. 斉藤ら（斉藤他, 2010）の分子

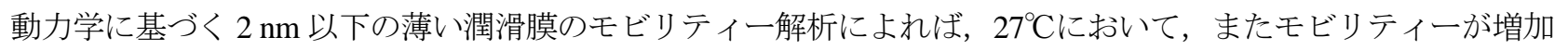
する $300^{\circ} \mathrm{C}$ の場合も, $\mathrm{h}<\sim 0.15 \mathrm{~nm}$ の領域で分子のモビリティーが常に零となっている. これは本理論との整合性 を示していると考えられる．ただしモビリティーが零となる膜厚さの值に関しては，今後さらに実験や分子動力 学の結果と比較検討する必要がある.

両者の理論のこの点に関する違いは, 従来の分離圧式(14)に比べて膜厚さによる密度変化を考慮した式(16)を用 いていることに起因している．そこで分離圧 $p$ と膜厚さ $h$ に関する微分である $d p / d h$ の $h$ に対する変化を比較的
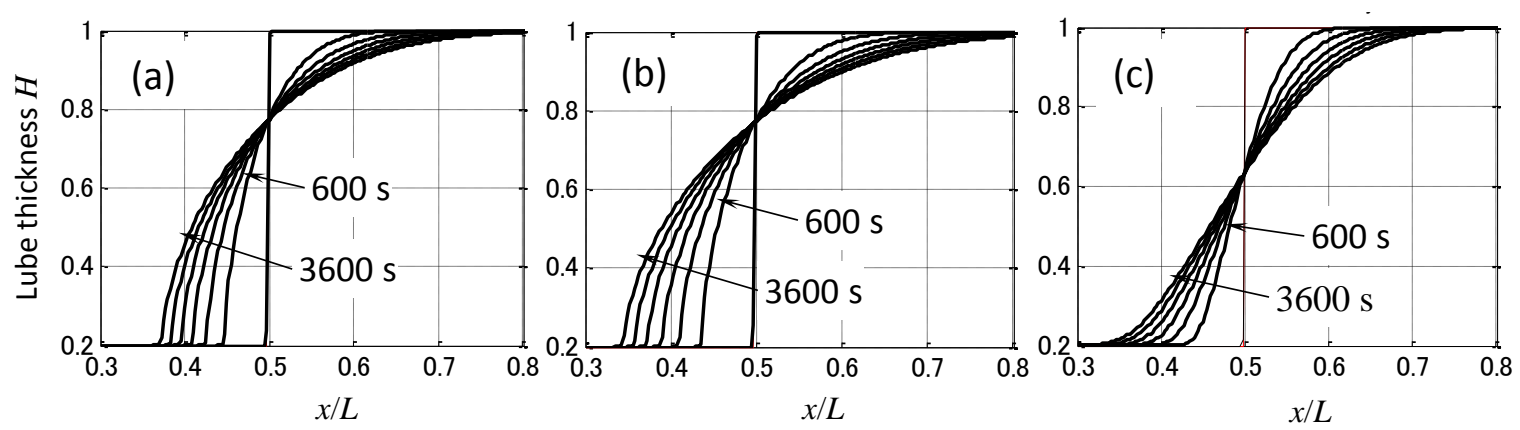

Fig. 4 Comparison of spreading profiles around film thickness step of $\Delta H=0.8$ when $h_{0}=0.5 \mathrm{~nm}$. (a) Submonolayer theory: $\mu_{m}=1 \mathrm{~Pa} \cdot \mathrm{s}, r_{\mu}=0.2$. (b) Submonolayer theory $\mu_{m}=1 \mathrm{~Pa} \cdot \mathrm{s}, r_{\mu}=0.3$. (c) Conventional theory: $\mu=90 \mathrm{~Pa} \cdot \mathrm{s}$. 

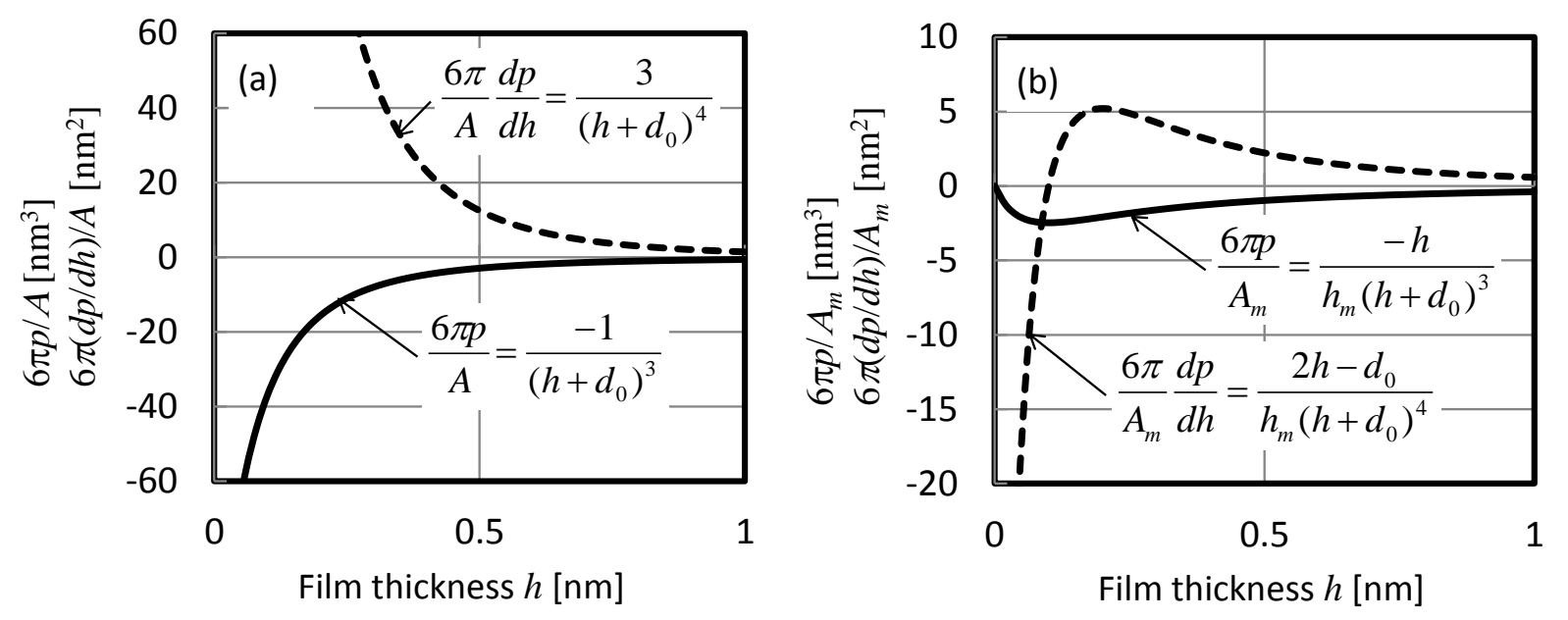

Fig. 5 Comparison of disjoining pressures and their derivatives between conventional theory and submonolayer theory.

(a) Conventional theory. (b) Submonolayer theory.

に図 5(a), (b)に示す. 図 5(a)に示す従来理論では, $h \rightarrow 0$ のとき $p$ は単調減少（負の值が増加）し，dp/dh は正值で 単調増加するのに対して, 図 5(b)に示す本理論では, $h \rightarrow 0$ のとき $p$ は $H=D_{0} / 2$ で極小值をとりゼロまで増加し, $d p / d h$ は正值増加 $\rightarrow$ 極大值 $\left(h=d_{0}\right) \rightarrow セ ゙ ロ ~\left(h=d_{0} / 2\right) \rightarrow$ 負值へと単調減少する. 図 5(a), (b)における $d p / d h$ の比較

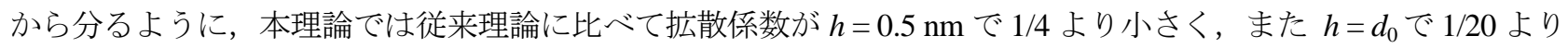
小さくなっており，このため本理論ではバルクに近い小さな粘度を与えても従来理論と同様な拡散特性を示すこ とが分かる。

従来理論では，膜厚さが零のとき，分離圧が最大（負の最小）となっており，これは物理的に不合理と考えら れる．従来はすべての論文において，分離圧として式(14)が用いられており，また式(14)を積分して得られる表面 エネルギーの式を用いて，単分子膜以下の潤滑膜が塗布されている表面の表面エネルギーの測定值から実験的に カットオフ距離 $d_{0}$ や Hamaker 定数が同定されている（doが大きい值に同定される主な理由はこの矛盾に起因す ると予想される)，潤滑膜厚さが零の場合は潤滑液膜の分離圧も表面エネルギーもゼロとなる方が合理的で，この ときむしろ固体壁面の van der Waals 力や表面エネルギーの効果を考慮すべきであると考えられる.

\section{$4 \cdot 3$ 近似理論の適用範囲}

図 3 および 4 に示した本理論の結果は厳密理論式(22)を用いたが, ここでは近似理論式(20)の解の有効範囲を調 べる. また厳密な理論式 $(22)$ は $r_{\mu}\left(=\mu_{m} / \mu_{0}\right)=1$ のとき $\alpha_{n}=0$ となり不定になるが, $r_{\mu}\left(=\mu_{m} / \mu_{0}\right)$ に 1 近傍の值を入 れたときの解と近似理論式(20)による $\alpha_{n}=0$ のときの解と比較する.

図 6 は㛜密理論式(22) と近似理論式(20)を用いて, 図 4 と同じ条件下 $\left(h_{0}=0.5 \mathrm{~nm}, h_{m}=1.5 \mathrm{~nm}\right.$, 段差 $\left.\Delta H=0.8\right)$ で, $r_{\mu}\left(=\mu_{m} / \mu_{0}\right)=0.5\left(\alpha_{n}=-0.167\right), 1\left(\alpha_{n}=0\right), 2\left(\alpha_{n}=0.333\right), 3\left(\alpha_{n}=0.667\right), 5\left(\alpha_{n}=1.33\right)$ のときの拡散形状を $(x-$
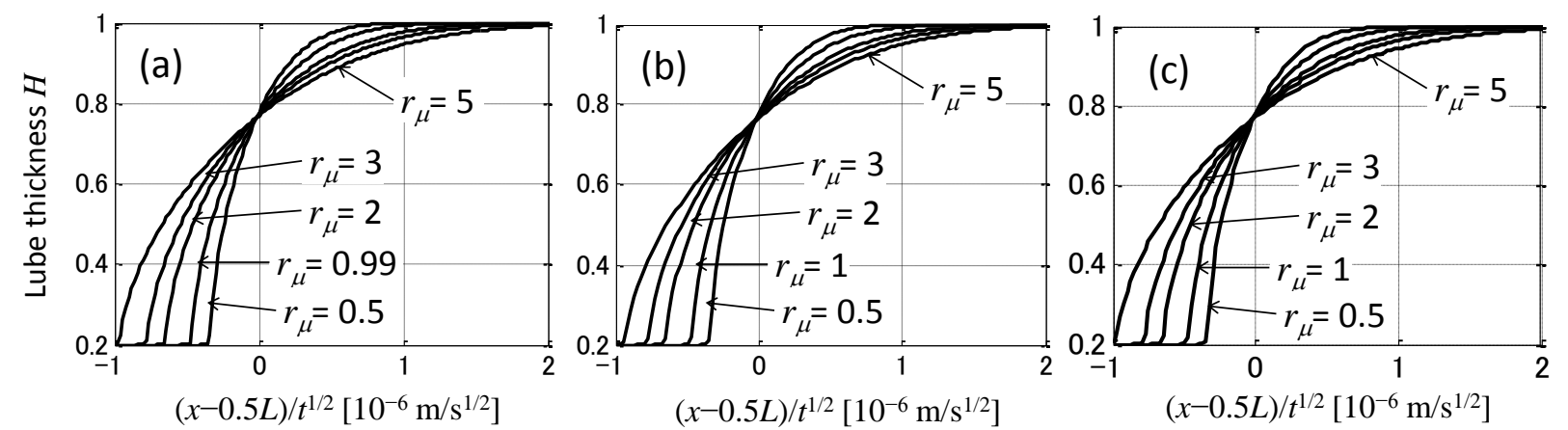

Fig. 6 Comparison of normalized spreading profile between submonolayer strict solutions and approximate solutions for various values of $r_{\mu}$. (a) Strict solution, (b) First order approximate solution, (c) Second order approximate solution. 
$0.5 L) / t^{1 / 2}$ の関数として示したものである. 経過時刻 $t=100 \mathrm{~s}$ のときの液膜形状を $(x-0.5 L) / t^{1 / 2}$ の関数として示し ているが，図3 から分かるように，任意の時間における拡散形状である. 図 6(a)は厳密理論解で, $r_{\mu}=1$ では解が 求まらないので $r_{\mu}=0.99$ としたときの結果を示している. 図6(b)は近似理論式(20)において $\alpha_{n}$ に関して 1 次項 までを採用した 1 次近似解，図 6(c) は式(20)のように $\alpha_{n}$ に関して 2 次項までを採用した 2 次近似解である.この 図から， $r_{\mu}=5\left(\alpha_{n}=1.33\right)$ の きは厳密解に比して 1 次近似解は拡散速度がやや遅く, 2 次近似解はわずかに速す ぎるが， $r_{\mu} \leq 3\left(\alpha_{n} \leq 0.667\right)$ ならば近似理論式は厳密理論式と同じ解を与えることがわかる．また厳密理論式も $r_{\mu}=$ 0.99 とすれば $r_{\mu}=1$ のときの十分よい近似解を与えることがわかる.

なお，単分子層以下の等価粘度がバルクの粘度に対して不連続的に変化し，一定の場合には，近似解で $\alpha_{n}=0$ とし， $\mu_{0}$ に単分子層以下の粘度を用いればよい.

\section{$4 \cdot 4$ 初期值に実験結果を用いたときの排除痕の修復特性}

次に, 測定された潤滑膜の排除痕の初期分布を初期值分布として，その後の拡散修復過程を本理論でシミュレ ーションした結果を実験結果および従来理論と比較する。 まず図 7(a)はヘッドスライダのタッチダウン操作によ って生じさせた Z-tetraol の潤滑剤の修復過程の OSA による測定結果で，既に既報（小野，2012）で示されている ものの引用である. OSA のピクセルサイズは $2 \mu \mathrm{m} \times 2 \mu \mathrm{m}$ で, ディスク半径方向に $2 \mu \mathrm{m}$ の間隔で測定している. また円周方向には $0.044^{\circ}$ 毎の 8192 個のデータを平均化している. なお OSA は 3 個のサンプル膜厚さをX-ray photoelectron spectroscopy で校正している．流動層の膜厚さは $h_{0}=0.24 \mathrm{~nm}$ で，バルクの粘度は $1 \mathrm{~Pa} \cdot \mathrm{s}$ である．曲 線の色は図 7(a)に示寸経過時間に対応しており， $\Delta h_{i}$ は $i$ 時間後の潤滑膜の分布を意味する.

図 7(b)，(c)は $A=0.5 \times 10^{-19} \mathrm{~J}, d_{0}=0.2 \mathrm{~nm}$ を用いて，従来理論により実験結果に近い結果が得られるように， 等価粘度をそれぞれ $\mu=60 \mathrm{~Pa} \cdot \mathrm{s} ， 120 \mathrm{~Pa} \cdot \mathrm{s}$ としたときの結果である. 計算では解析領域を $500 \mu \mathrm{m}$ とし，両端で閏 滑膜高さの微分がゼロとしている．既報のように， $A=1.0 \times 10^{-19} \mathrm{~J} ， d_{0}=0.3 \mathrm{~nm}$ を用いると， $\mu=50 \mathrm{~Pa} \cdot \mathrm{s}, 100 \mathrm{~Pa}$ ·s のときそれぞれ図 7(b), (c) とほぼ同じ結果が得られる. 図7(b)に示す $\mu=60 \mathrm{~Pa} \cdot \mathrm{s}$ の場合には，排除溝が深い 領域で経過時間が数時間の範囲の修復過程を模擬できているが，排除溝が浅くなる 1 日〜数日後の修復速度は実
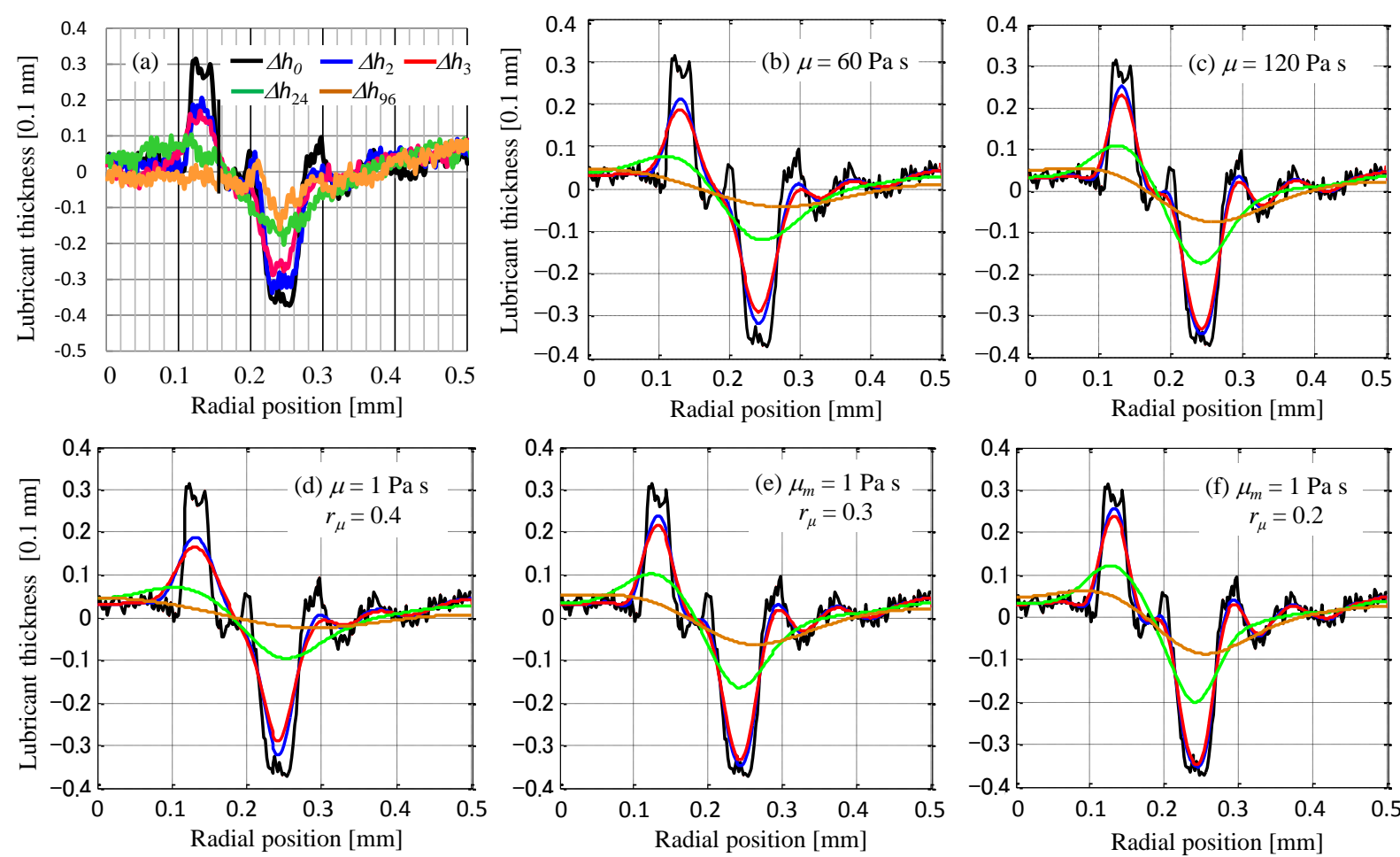

Fig. 7 Comparison of simulated results for experimental replenishment process in depleted scar between submonolayer diffusion theory and conventional theory. (a) Experimental replenishment profiles. (b), (c) Conventional theory. (d), (e), (f) Submonolayer theory. 
際より速くなる. 1 日〜数日後の浅い排除溝の修復過程は, 図 7(c)に示すように $\mu=120 \mathrm{~Pa} \cdot \mathrm{s}$ 程度にしないと実際 に近い結果が得られない.

そこで, 単分子層以下の液膜に関する本理論により, $\mu_{m}=1 \mathrm{~Pa} \cdot \mathrm{s}$ として, 図7(b), (c) に近い結果が得られる $r_{\mu}(=$ $\left.\mu_{m} / \mu_{0}\right)=0.4,0.3,0.2$ のきの修復過程をそれぞれ図7(d), (e), (f)に示寸. 図7(d)の $r_{\mu}=0.4$ の場合が図7(b)の従来理論 による数時間内の特性と同じ特性を示している. しかし 1 日後〜数日後の浅い溝の修復速度は従来理論より少し 速い. 1 日後〜数日後の修復特性が実際に近い図7(c) と同様な特性は図7(e) と(f)の中間の $r_{\mu}=0.25$ のときに得ら れるといえる。この結果は，本理論においては，バルクの粘度を単分子膜の粘度として用いると，固定壁の等価 粘度をバルクの值の2.5〜 5倍にすればよいことを意味する.よって本理論は, 既に述べたScarpllaら (Scarplla, et al., 2003)のblow-off 実験の結果に整合した粘度を用いて実際の特性をかなりよく表現することができる. 本理論によ り, 従来理論で実際の修復特性を得るにはあまりに大きな等価粘度を用いなければならない, といら問題を解決 できることが明らかになった．しかし図7(a)に示した実際の修復特性を模擬するには，排除溝が深い場合に対し て浅い場合の粘度を約 2 倍大きくする必要があるのは従来理論と同様である.ここには示さないが，単分子以下 の層の粘度がバルクの值 $\mu_{\mathrm{m}}$ から不連続的に変化し, 一定值 $\mu_{0}$ をとるという条件で計算したところ, $\mu_{0}=1.5,3,5 \mathrm{~Pa}$ ·sでそれぞれ図7(d), (e), (f)に近い特性が得られ，排除溝が深い場合と浅い場合の同定粘度が異なるという問題は 同じであった．この点は今後さらに実験的および解析モデルの観点からも検討する必要がある.

\section{5. 結 論}

磁気ディスク装置のヘッド・ディスク間の浮上すきまの狭小化の险路となっているへッド摩耗に影響する単分 子層以下の厚さの流動潤滑膜の流動特性を明らかにするため, 単分子層以下の液膜の平均的な拡散・修復流動に 関する一次元方向の拡散方程式を定式化した，基礎となる概念は，計測される単分子層以下の潤滑膜厚さは，被 覆率 1 の単分子膜の密度に対する分子密度で表現されるとするものである. よって質量流量は膜厚の低下によっ て減少し, Hamaker 定数も関係する面の密度即ち膜厚さに比例するので分離圧式の膜厚依存性も従来の式と異な る. また単分子層以下の膜厚内においても平均速度が厚さ方向に変化があり, 固体壁面でスリップがなく速度が 零になると仮定した. 粘度の膜厚さ依存性は, 密度変化と極性基による壁面結合力を考慮して壁面からの距離で 線形的に変化するモデルを採用した。 これらの仮定とモデルに基づき, 自由表面をもつ薄膜の質量保存則を用い て拡散方程式を導出した。得られた単分子層以下の液膜の拡散方程式を用いて液膜段差境界の拡散特性および既 報の修復特性の実験結果をシミュレーションし, 従来の連続体力学に基づく拡散方程式と比較した. 得られた拡 散・修復方程式の特徵を以下に記す。

(1) 厳密な流量積分による拡散方程式と共に, 粘度比と膜厚さ比に関する無次元パラメータ $\alpha_{n}$ が1より十分小さ い場合に有効な近似拡散方程式をも導出し，厳密解との比較によりその有効性を示した。 なお，近似拡散方程式 において， $\alpha_{n}=0$ とすると，単分子層以下の液膜における粘度 $\mu_{0}$ が一定で，バルクの粘度から不連続的に変化す る場合をも解析できる.

(2) 単分子層以下の液膜流動に関する本拡散方程式は, 液膜厚さの二乗に関する非線形方程式で表される. これは 分子密度が膜厚さに比例するからである. しかし液膜段差境界が拡散により変化する形状は従来の線形拡散方程 式と同様に経過時間の平方根で割ると単一曲線で表される.

(3) 拡散によるステップ的な液膜境界の変化は, 従来理論より境界近傍の上部の膜厚さの減少に比べて, 下部の 拡散領域の膜厚の増加が大きい。これは密度の高い領域の液体が密度の低い領域に拡散するので, 密度一定とす る従来理論より膜厚さが小さい領域で体積が増加するように見えるからである.

(4) 本理論により極性末端基をもつ潤滑膜の排除痕の修復特性を, 単分子層以上の領域の粘度をバルクの粘度と し，固定壁面における等価粘度をその数倍に選べば，実際の修復特性をかなりよく模擬することができる．この 結果は, blow-off 実験で測定されている数分子層から単分子層以下の粘度変化に整合しており, 本理論の優位性 が示された，本理論により，従来理論では著しく高い等価粘度を用いないと実際に近い特性を得ることができな いという問題を解決することができた. 
(5) 本理論により, 排除溝が深い領域における実際の修復特性を得られる粘度は, 浅い領域における実際の修復 特性を得られる粘度の約 $1 / 2$ である. この問題は従来理論と同じであり, この原因の解明は今後の課題である.

(6) Hamaker 定数が膜厚さに比例するとする本理論による分離圧式は, 潤滑液膜厚さがゼロのときゼロとなる.こ の結果は潤滑液膜厚さがゼロのとき最大の值をとる従来の分離圧式より合理的であると考えられる．本分離圧式 を用いたときの等価的な拡散係数はカットオフ距離の半分以下で負になるため，この領域への拡散は不可能とい う結果が得られる.この結果に整合寸る分子動力学解析結果も示されているが，今後検証されるべき興味深い理 論的帰結である.

本理論の妥当性と限界性，および粘度の膜厚さ依存性，単分子膜以下の分離圧の膜厚さ依存性はステップ的な 潤滑膜境界の拡散現象, blow-off実験, 排除溝への修復特性等の実験結果, 分子動力学などとの比較を通じて更に 解明する必要がある. また本論文で提起した一次元のsubmonolayer 拡散方程式をLaplace圧力をも考慮して2次元 に拡張すること，さらにそれを用いてナノメニスカス形成現象やlube pickup現象などを理論的に解明することが 今後の課題である.

謝辞

本研究は，JSPS 研究費 基盤研究(C) 24560154 の補助を受けたことを付記し，謝意を表する.

\section{文献}

Canchi, S. V. and Bogy, D. B., Slider-lubricant interactions and lubricant distribution for contact and near contact recording conditions, IEEE Transactions on Magnetics, Vol. 47, No. 7 (2011), pp. 1842-1848.

Granick, S., Motions and relaxations of confined liquids, Science, Vol. 253, No. 5026 (1991), pp. 1374-1379.

Israelachvili, J. N., Intermolecular and surface forces, Second Edition (1992), Academic Press.

（近藤保，大島広行訳，分子間力と表面力，第2版 (1996)，pp. 172-196，朝倉書店）

Itoh, S., Fukuzawa, K., Ando, T., Hamamoto, Y., Zhang, H. and Mitsuya, Y., Fiber wobbling method for dynamic viscoelastic measurement of liquid lubricant confined in molecularly narrow gaps. Tribology. Letters, Vol. 30, No. 3 (2008), pp. 177-189.

Kawaguchi, M., Choi, J., Kato, T. and Tanaka, K., A Study of friction properties of zdol on magnetic disk surface, IEEE Transactions on Magnetics, Vol. 39, No. 5 (2003), pp. 2483-2485.

松岡広成, 福井茂寿, 近接する複合層に働くファンデルワールスカの汎用的近似式の導出（超微小寸きま浮動形 磁気ヘッドスライダの静的浮上解析への適用), 日本機械学会論文集 C 編, Vol.69, No.686 (2003), pp.2810-2817.

Matsuoka, H., Ono, K. and Fukui, S., Study on surface energy on ultra-thin film, Journal of Advanced Mechanical Design, Systems, and Manufacturing, Vol. 4, No. 1 (2010), pp. 391-396.

Mate, C. M., Tribology on the Small Scale, Oxford University Press (2008), p. 144-162. （三矢保永，小野京右訳，マイクロ・ナノスケールのトライボロジー (2013),pp. 155-175, 吉岡書店)

Mate, C. M., Taking a fresh look at disjoining pressure of lubricants, IEEE Transactions on Magnetics, Vol. 47, No. 1 (2011), pp. 124-130.

Mate, C. M., Anomalous diffusion kinetics of the precursor film that spreads from polymer droplets, Langmuir, Vol. 28 (2012), pp.16821-16827.

Mate, C. M., Spreading kinematics of lubricant droplets on magnetic recording disks, Tribology Letters, Vol. 84, No. 4 (2013), pp. 532-534.

Matthes, L., Brunner, R., Knigge, B. and Talke, F. E., Investigation of head burnishing of thermal flying height control sliders, CD-ROM of ISPS2013, No.2013-2909, June 24-25 (2013), Santa Clara, CA, USA.

Marchon, H. and Karis, T. E., Poiseuille flow at a nanometer scale, Europhysics. Letters, Vol. 74, No. 2 (2006), pp. 294-298. 小野京右, 粗さ表面のLennard-Jones 表面力を考慮した球面と平面の接触特性の数值解析法, 日本機械学会論文集 C編, Vol.77, No.778 (2011), pp.2522-2536. 
小野京右, 潤滑薄膜の修復特性解析に基づく突起接触による磁気ヘッドの摩耗而久性評価, 日本機械学会論文集 C編, Vol.79, No.798 (2013), pp.392-407.

斉藤洋子, 加賀爪明子, 宮崎真理子, 佐々木直哉, 分子動力学による磁気ディスク潤滑膜剪断挙動の温度依存性, 2010 トライボロジー会議春予稿集 (2010), pp. 139-140.

Scarpulla, M. A., Mate, C. M. and Carter, M. D., Air shear driven flow of thin perfluoropolyether polymer films, Journal of Chemical Physics, Vol. 118, No. 7 (2003), pp. 3368-3375.

Tani, H., Sakamoto, K. and Tagawa, N., Conformation of ultrathin PFPE lubricants with different structure on magnetic disks-Direct observation and MD simulation, Vol. 45, No. 11 (2009), pp. 5050-5054.

Tani, H., Matsutome, T. and Tagawa, N., Adhesion an dfriction behavior of magnetic disks with ultrathin perfluoropolyether lubricant films having differenct end-groups measured using pin-on-disk test, IEEE Transactions on Magnetics, Vol. 49, No. 6 (2013), pp. 2638-2644.

Waltman, R. J., Deng, H., Wang, G. J., Zhu, H. and Tyndall, G. W., The effect of PFPE film thickness and molecular Polarity on the pick-up of disk lubricant by a low-flying slider, Tribology Letters, Vol. 39, No. 2 (2010), pp. 211-219.

\section{References}

Canchi, S. V. and Bogy, D. B., Slider-lubricant interactions and lubricant distribution for contact and near contact recording conditions, IEEE Transactions on Magnetics, Vol. 47, No. 7 (2011), pp. 1842-1848.

Granick, S., Motions and relaxations of confined liquids, Science, Vol. 253, No. 5026 (1991), pp. 1374-1379.

Israelachvili, J. N., Intermolecular and Surface Forces, Second Edition, Academic Press (1992).

Itoh, S., Fukuzawa, K., Ando, T., Hamamoto, Y., Zhang, H. and Mitsuya, Y., Fiber wobbling method for dynamic viscoelastic measurement of liquid lubricant confined in molecularly narrow gaps. Tribology. Letters, Vol. 30, No. 3 (2008), pp. 177-189.

Kawaguchi, M., Choi, J., Kato, T. and Tanaka, K., A Study of friction properties of zdol on magnetic disk surface, IEEE Transactions on Magnetics, Vol. 39, No. 5 (2003), pp. 2483-2485.

Matsuoka, H. and Fukui, S., Generalized approximation of van der Waals force between multilayers (Application to analysis of static characteristics of a magnetic head slider), Transactions of the Japan Society of Mechanical Engineers, Series C, Vol.69, No.686 (2003), pp.2810-28177 (in Japanese).

Matsuoka, H., Ono, K. and Fukui, S., Study on surface energy on ultra-thin film, Journal of Advanced Mechanical Design, Systems, and Manufacturing, Vol. 4, No. 1 (2010), pp. 391-396.

Mate, C. M., Tribology on the Small Scale, Oxford University Press (2008), p. 144-162.

Mate, C. M., Taking a fresh look at disjoining pressure of lubricants, IEEE Transactions on Magnetics, Vol. 47, No. 1 (2011), pp. 124-130.

Mate, C. M., Anomalous diffusion kinetics of the precursor film that spreads from polymer droplets, Langmuir, Vol. 28 (2012), pp.16821-16827.

Mate, C. M., Spreading kinematics of lubricant droplets on magnetic recording disks, Tribology Letters, Vol. 84, No. 4 (2013), pp. 532-534.

Matthes, L., Brunner, R., Knigge, B. and Talke, F. E., Investigation of head burnishing of thermal flying height control sliders, CD-ROM of ISPS2013, No.2013-2909, June 24-25 (2013), Santa Clara, CA, USA.

Marchon, H. and Karis, T. E., Poiseuille flow at a nanometer scale, Europhysics. Letters, Vol. 74, No. 2 (2006), pp. 294-298.

Ono, K., Numerical analysis method of adhesive contact mechanics between a sphere and a flat considering Lennard-Jones surface forces of noncontacting rough surfaces, Transactions of the Japan Society of Mechanical Engineers, Series C, Vol.77, No.778 (2011), pp.2522-2536 (in Japanese).

Ono, K., Evaluation of head wear durability due to asperity contact based on replenishment velocity analysis of sub-monolayer lubricant in hard disk drives, Transactions of the Japan Society of Mechanical Engineers, Series C, Vol.79, 
No.798 (2013), pp.392-407 (in Japanese).

Saito, Y. Kagatsume, A., Miyazaki, M., Sasaki, N., Molecular dynamics simulation for lubricant shear properties on magnetic disk under heating, Proceedings of JAST Tribology Conference, Spring (2010), pp. 139-140 (in Japanese).

Scarpulla, M. A., Mate, C. M. and Carter, M. D., Air shear driven flow of thin perfluoropolyether polymer films, Journal of Chemical Physics, Vol. 118, No. 7 (2003), pp. 3368-3375.

Tani, H., Sakamoto, K. and Tagawa, N., Conformation of ultrathin PFPE lubricants with different structure on magnetic disks-Direct observation and MD simulation, Vol. 45, No. 11 (2009), pp. 5050-5054.

Tani, H., Matsutome, T. and Tagawa, N., Adhesion and friction behavior of magnetic disks with ultrathin perfluoropolyether lubricant films having different end-groups measured using pin-on-disk test, IEEE Transactions on Magnetics, Vol. 49, No. 6 (2013), pp. 2638-2644.

Waltman, R. J., Deng, H., Wang, G. J., Zhu, H. and Tyndall, G. W., The effect of PFPE film thickness and molecular polarity on the pick-up of disk lubricant by a low-flying slider, Tribology Letters, Vol. 39, No. 2 (2010), pp. 211-219. 